\title{
The Use of Synthetic Peptides in the Formation of Biophysically and Biologically Active Pulmonary Surfactants ${ }^{1}$
}

\author{
SUSAN D. REVAK, T. ALLEN MERRITT, MIKKO HALLMAN, GREGORY HELDT, \\ ROBERT J. LA POLLA, KENWAY HOEY, RICHARD A. HOUGHTEN, AND \\ CHARLES G. COCHRANE
}

\begin{abstract}
Departments of Immunology [S.D.R., C.G.C.] and Molecular Biology [R.A.H.], Research Institute of Scripps Clinic, La Jolla. California 92037; Division of Neonatal/Perinatal Medicine [T.A.M., G.H.], Department of Pediatrics, University of California at San Diego, San Diego, California 92103; Children's Hospital [M.H.]. The University of Helsinki, Helsinki, Finland; R. W. Johnson Pharmaceutical Research Institute [R.J.L.P., K.H.],
\end{abstract} San Diego, California 92121

\begin{abstract}
Synthetic pulmonary surfactants consisting of mixtures of phospholipids with synthetic peptides based on the amino acid sequence of human surfactant apoprotein SP-B were prepared. These surfactants were analyzed for their ability to lower surface tension on a pulsating bubble surfactometer and for their capacity to improve lung compliance and increase alveolar expansion in a fetal rabbit model of surfactant deficiency. The data demonstrate that several peptides, ranging from 17 to 45 residues in length, matching the carboxy-terminal sequence of the SP-B protein, when appropriately recombined with the phospholipids dipalmitoylphosphatidylcholine and phosphatidylglycerol (3:1), are capable of producing a synthetic surfactant with biophysical and biologic activity approaching that of human surfactant derived from amniotic fluid. (Pediatr Res 29: 460-465, 1991)
\end{abstract}

\section{Abbreviations}

DPPC, dipalmitoylphosphatidylcholine

IA, iodoacetic acid

PG, phosphatidylglycerol

PL, phospholipid

SP, surfactant protein

The presence of two hydrophobic, low molecular weight apoproteins in mammalian pulmonary surfactant has been shown $(1-19)$, and cDNA clones have been isolated that predict the amino acid sequences of their precursor molecules $(3-5,10,15)$. The importance of these apoproteins, termed SP-B and SP-C (20) in the ability of natural or synthetic surfactants to be able to reduce surface tension at the epithelial air/liquid interface in the lung has been the subject of several recent papers $(2,7,10$, $11,13-15,17-19,21-23)$. Human surfactant isolated from term amniotic fluid (24-26), as well as heterologous surfactants consisting of lung mince or airway lavage lipid extracts from calves

Received June 25, 1990; accepted December 7, 1990

Correspondence: Susan D. Revak, Dept. of Immunology, IMM12, Research Institute of Scripps Clinic, 10666 North Torrey Pines Road, La Jolla, CA 92037.

Supported by Grants HL23584, HL35036, and FDA 000112 from the National Institutes of Health, Grant RR00169 from the Public Health Service, The Finnish Academy, the Sigrid Juselius Foundation, and Johnson \& Johnson.

1 Presented in part, at the International Meeting on Surfactant Research on the River Rhine, November 11-17,1989 and at the annual meeting of the Society for Pediatric Research, May 6-10, 1990, in Anaheim, CA. or swine, or synthetic lipids, generally in combination with SP$\mathrm{B}$ and SP-C $(7,10,11,13-15,17-19,21-23,27)$, are being evaluated for their potential use in surfactant replacement therapies.

Our previous studies (10) and those of Curstedt et al. (2), and $\mathrm{Yu}$ and Possmayer (19), suggested that when recombined with PL, SP-B resulted in greater surface tension lowering and biologic activity than did SP-C. For this reason, we decided to focus our attention on this protein. SP-B, also called SP-18 (4, 10), SPL(Phe) (3), PSP-B (5), and SAP-6-14 (7, 16, 17, 23), has been shown to be a disulfide-linked dimer of two identical polypeptides of approximately $9000 \mathrm{D}$ having an amino terminal sequence of phe-pro-ile-pro-leu-pro-tyr- (human) $(3,5,10)$. Data based on amino acid compositions (10) and fast atom bombardment mass spectroscopy (unpublished observations) have led us to conclude that human SP-B is $80-81$ residues in length. The sequence is shown in Figure 1.

To investigate the mechanisms by which SP-B protein augments the surfactant capacity of PL, peptides were synthesized that conform to portions of the native sequence of this protein. These peptides could be combined with PL to reconstitute the biophysical and biologic activities of natural surfactant. We report here the results of studies, using the pulsating bubble surfactometer to measure the capacity of these synthetic surfactants to lower surface tension at an air/liquid interface and the fetal rabbit model to determine their ability to increase lung compliance and alveolar expansion.

\section{MATERIALS AND METHODS}

Preparation of purified SP-B monomer, dimer, and oligomers. SP-B was isolated from human amniotic fluid surfactant as described previously (10). One hundred $\mu \mathrm{g}$ of SP-B, in a volume of $206 \mu \mathrm{L}$ methanol, were incubated with $5.14 \mathrm{mg}$ DTT (Sigma Chemical Co, St. Louis, MO) in $17 \mu \mathrm{L}$ methanol, for $1 \mathrm{~h}$ at $37^{\circ} \mathrm{C}$. Analysis of $2 \mu \mathrm{L}$ on SDS-PAGE showed the SP-B to be approximately $70 \%$ reduced as noted by a shift in band position from $18000 \mathrm{D}$ to approximately $9000 \mathrm{D}$. The SP-B/DTT mixture was allowed to incubate an additional $30 \mathrm{~min}$ at $37^{\circ} \mathrm{C}$ and overnigh at room temperature under $\mathrm{N}_{2}$. A $10-\mu \mathrm{L}$ aliquot was removec and $20 \mu \mathrm{L}$ containing $40 \mu \mathrm{Ci}$ of ${ }^{3} \mathrm{H}-\mathrm{IA}$ (ICN Radiochemicals Irvine, CA) in water were added. After $30 \mathrm{~min}$ of incubation a $37^{\circ} \mathrm{C}$, this aliquot was added back to the SP-B/DTT mixture along with $27.74 \mathrm{mg}$ unlabeled IA in $25 \mu \mathrm{L}$ water. Alkylatior was allowed to proceed for $1 \mathrm{~h}$ at $37^{\circ} \mathrm{C}$. Chloroform and $\mathrm{HC}$ were added to make the final mixture chloroform/methanol, $1: 1$ $+5 \% 0.1 \mathrm{~N} \mathrm{HCl}$. The sample was then loaded onto a $1 \times 40 \mathrm{cr}$ 
Sephadex LH-60 (Pharmacia Fine Chemicals, Uppsala, Sweden) column. The column was run at a flow rate of $2.5 \mathrm{~mL} / \mathrm{h}$ using the acidified chloroform/methanol buffer, and fractions of 0.5 $\mathrm{mL}$ were collected.

Fractions were analyzed for the presence of ${ }^{3} \mathrm{H}$, unreacted DTT, IA, and SP-B proteins (by SDS-PAGE). Monomer, dimer, and higher molecular weight oligomers, all carrying a trace amount of ${ }^{3} \mathrm{H}$, were found in fractions $11-19$, well before excess DTT, DTT-IA, and breakdown products of IA were eluted in fractions $32-60$. Figure 2 shows the molecular weight characteristics of the various SP-B forms separated on this column. Pools were made of oligomer/dimer (fractions 11 and 12), dimer (fractions 13 and 14), and monomer (fractions 16-19). The pools were dried under $\mathrm{N}_{2}$, lyophilized for $1 \mathrm{~h}$, redissolved in $500 \mu \mathrm{L}$ methanol, and quantitated by amino acid compositional analysis.

Peptide synthesis. Peptides were prepared by solid-phase synthesis according to the methods of Houghten (28) or Merrifield (29). In the latter case, an Applied Biosystems (Foster City, CA) $430 \mathrm{~A}$ or $431 \mathrm{~A}$ peptide synthesizer was used. Four equivalents of amino acid derivative were activated with equimolar 1-hydroxybenzotriazole and dicyclohexylcarbodiimide. This resulting ester was reacted with the peptide-phenylacetamidomethyl resin for $60 \mathrm{~min}$ to effect peptide bond formation. Aspartic acid, glutamic acid, threonine, and serine were protected as the benzyl esters, arginine by the tosyl group, tyrosine as the orthobromobenzyloxycarbonyl ester, and cysteine as the methylbenzyl ester. The sulfur group of methionine was not protected during peptide synthesis. The trifluoroacetic acid-treated peptide resins were cleaved by the hydrogen fluoride/anisole procedure $(30,31)$ at $-4^{\circ} \mathrm{C}$ for $1 \mathrm{~h}$. The peptides were extracted from the resin matrix using $70 \%$ acetic acid/water or neat trifluoroacetic acid, diluted with water, and lyophilized. The crude product (typically 300 $500 \mathrm{mg}$ ) was purified on a Waters Auto 500 preparative HPLC (Waters Associates, Milford, MA) fitted with a 2-inch PrepPak cartridge packed with Vydac C18 $30-\mu \mathrm{m}$ particles with $300-\AA$ pore size (Western Analytical Products, Temecula, CA). These peptides were eluted off the column with a gradient between water and acetonitrile, both containing $0.1 \%$ trifluoroacetic acid (vol/vol). The purified products were characterized by amino acid analysis, peptide content determination, analytical HPLC analysis (Vydac C18, 5- $\mu \mathrm{m}$ particles with $300-\AA$ pore size, $4.6 \times$ $250 \mathrm{~mm}$ ) and/or fast atom bombardment mass spectroscopy analysis. Peptides were stored in a vacuum desiccator at room temperature.

Preparation of synthetic surfactants. All PL were purchased from Avanti Polar-Lipids, Inc. (Pelham, AL). L- $\alpha$-dipalmitoyl lecithin (DPPC) and PG (egg) were mixed in chloroform in a 3:1 (wt/wt) ratio.

Peptide in chloroform/methanol (generally $50 \%$ chloroform, $50 \%$ methanol) was added to PL in chloroform at a ratio of $1: 10$ (wt/wt) unless stated otherwise. The mixture was incubated at $43^{\circ} \mathrm{C}$ for $10 \mathrm{~min}$ and then dried under $\mathrm{N}_{2}$. In most cases, the sample was further dried by a $15-\mathrm{min}$ exposure to vacuum. Water was then added in an amount calculated to equal $90 \%$ of the volume necessary to give a final lipid concentration of 4,10 , or $20 \mathrm{mg} / \mathrm{mL}$. The mixture was incubated for $1 \mathrm{~h}$ at $43^{\circ} \mathrm{C}$ with periodic vortexing. A volume of $6 \% \mathrm{NaCl}$ equal to $10 \%$ of the volume necessary to give the desired PL concentration was added, and the mixture was incubated an additional $10 \mathrm{~min}$ at $43^{\circ} \mathrm{C}$. In some cases, the final mixture was subjected to three cycles of freezing and thawing.

Surfactant activity assays. Methods for the assessment of surfactant activity measured in vitro using the pulsating bubble surfactometer and in vivo by the generation of static pressurevolume curves in 27-d gestation fetal rabbits after treatment with surfactant have both been described in detail previously (32). The current study also incorporates the use of dynamic pulmonary compliance measurements in the fetal rabbit model. Briefly, the technique involves the placement of the tracheostomized fetuses, after the administration of the test surfactants, into a 12place, thermostated plethysmograph, where they are ventilated in parallel for up to $60 \mathrm{~min}$ at a peak inspiratory pressure of 25 $\mathrm{cm} \mathrm{H}_{2} \mathrm{O}$, and a positive end expiratory pressure of $0-3 \mathrm{~cm} \mathrm{H}_{2} \mathrm{O}$, using an inspiratory time of $0.5 \mathrm{~s}$ (30 breaths $/ \mathrm{min})$. Air flow and airway pressure were measured at 10 -min intervals with a pressure transducer (Celesco, Canoga Park, CA) and the signals were digitally analogued into a microcomputer for calculation of dynamic compliance and pulmonary resistance. Synthetic surfactant samples for in vivo assays were prepared as described above and instilled according to one of the following two protocols: 1) For static pressure/volume experiments, $2 \mathrm{mg}$ of PL \pm peptide (or $2 \mathrm{mg}$ natural human surfactant) in a volume of 0.1 $\mathrm{mL}$ were injected into the trachea and the animal immediately connected to the ventilator. 2) For dynamic compliance experiments, $0.2 \mathrm{~mL}$ of $20 \mathrm{mg} / \mathrm{mL}$ surfactant, followed by $0.15 \mathrm{~mL}$ air, $0.1 \mathrm{~mL}$ physiologic saline, and $0.3 \mathrm{~mL}$ air were injected from one syringe into the trachea. Two subsequent aliquots of $0.3 \mathrm{~mL}$ air were given before the animal was connected to the ventilator.

SDS-gel electrophoresis. PAGE in $16 \%$ polyacrylamide plus SDS was performed in $3 \times 7 \mathrm{~cm}$ mini-gels according to the method of Laemmli (33). Methods of fixation and staining have been described previously (10).

Hydrophobic moments. Hydrophobic moments for various peptides were calculated according to the method of Eisenberg (34).

\section{RESULTS}

$S P-B$ dimer versus monomer. To determine whether the monomeric SP-B polypeptide would possess activity, a study was designed to compare activities of dimeric and monomeric SP-B. Native SP-B was subjected to reduction and alkylation, which typically results in reduction of $70-80 \%$ of the protein, and separated by chromatography on LH-60 Sephadex into pools containing monomer, dimer, and a mixture of dimer plus higher molecular weight oligomers. These polypeptides, as well as untreated SP-B, were then combined with the phospholipids DPPC and $\mathrm{PG}$ at a weight ratio of $0.5 \%$ protein to PL. The mixtures were analyzed for their ability to lower the surface tension on the pulsating bubble surfactometer. The results are shown in Table 1 . At $15 \mathrm{~s}$, the surfactant mixture containing monomer was slightly less active than those containing dimer or dimer plus oligomers; at the other time points, all three show comparable activities. Interestingly, the dimer that had been exposed to the reduction and alkylation procedure was significantly less active than native SP-B, even though native SP-B is $>90 \%$ dimer. This suggests that alkylation of free sulfhydryl groups may inhibit activity. More ${ }^{3} \mathrm{H}-\mathrm{IA}$ was bound per $\mu \mathrm{g}$ of monomer than dimer or oligomer $(279 \mathrm{cpm} / \mu \mathrm{g}$ monomer, $214 \mathrm{cpm} / \mu \mathrm{g}$ dimer, and 198

\section{SP-B}

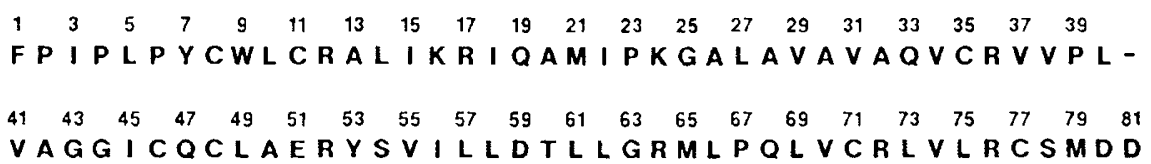

Fig. 1. Amino acid sequence of human pulmonary surfactant apoprotein SP-B isolated from term amniotic fluid. Single-letter amino acid codes are used. 


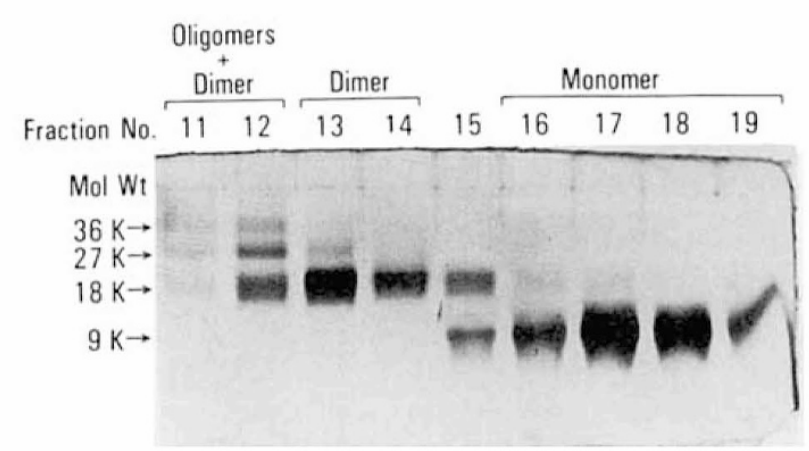

Fig. 2. Silver-stained SDS-PAGE of sequential fractions of LH-60 Sephadex chromatographic separation of SP-B oligomers plus dimer (fractions 11 and 12), dimer (fractions 13 and 14) and monomer (fractions 16-19) after reduction and alkylation of native SP-B protein.

Table 1. Minimum surface tension in pulsating bubble*

\begin{tabular}{lrrr}
\hline & \multicolumn{1}{c}{$15 \mathrm{~s}$} & \multicolumn{1}{c}{$1 \mathrm{~min}$} & \multicolumn{1}{c}{$5 \mathrm{~min}$} \\
\hline PL + & $48.6 \pm 0.2$ & $48.0 \pm 0.0$ & $41.6 \pm 0.8$ \\
PL + monomer $\ddagger$ & $23.5 \pm 2.4$ & $18.0 \pm 0.4$ & $13.9 \pm 1.8$ \\
PL + dimer & $16.9 \pm 0.2$ & $17.1 \pm 0.4$ & $14.9 \pm 2.4$ \\
PL + dimer/oligomers & $17.4 \pm 0.2$ & $15.5 \pm 1.0$ & $9.6 \pm 0.6$ \\
PL + SP-B & $2.9 \pm 2.5$ & $4.1 \pm 1.2$ & $3.3 \pm 1.7$ \\
\hline
\end{tabular}

* Pulsation of $20 \mathrm{cycles} / \mathrm{min}$ started $10 \mathrm{~s}$ after bubble formation. All values are in dynes. $\mathrm{cm}^{-1}$ and are the mean \pm SEM of at least three determinations.

$\dagger \mathrm{PL}=\mathrm{DPPC}: \mathrm{PG}, 3: 1,4 \mathrm{mg} / \mathrm{mL}$

$\ddagger$ Proteins were $0.5 \%$ by weight compared with PL.

Table 2. Minimum surface tensions in pulsating bubble assay*

\begin{tabular}{lccrc}
\hline & $15 \mathrm{~s}$ & \multicolumn{1}{c}{$1 \mathrm{~min}$} & \multicolumn{1}{c}{$5 \mathrm{~min}$} & $\mathrm{uH} / \mathrm{N} \dagger$ \\
\hline $\mathrm{PL} \neq$ & $49.0 \pm 0.0$ & $48.8 \pm 0.3$ & $46.3 \pm 0.4$ & \\
$\mathrm{PL}+\mathrm{p} 1-15 \S$ & $28.6 \pm 0.8$ & $24.3 \pm 0.7$ & $8.4 \pm 2.1$ & 0.19 \\
$\mathrm{PL}+\mathrm{p} 11-25$ & $24.7 \pm 2.3$ & $15.1 \pm 1.5$ & $1.0 \pm 0.1$ & 0.52 \\
$\mathrm{PL}+\mathrm{p} 21-35$ & $24.5 \pm 0.1$ & $23.5 \pm 0.1$ & $22.1 \pm 0.2$ & 0.07 \\
$\mathrm{PL}+\mathrm{p} 31-45$ & $32.1 \pm 0.2$ & $28.0 \pm 0.6$ & $23.1 \pm 0.3$ & 0.44 \\
$\mathrm{PL}+\mathrm{p} 41-55$ & $36.5 \pm 0.5$ & $33.5 \pm 1.5$ & $20.2 \pm 1.2$ & 0.15 \\
$\mathrm{PL}+\mathrm{p} 51-65$ & $29.8 \pm 0.4$ & $25.3 \pm 1.6$ & $20.0 \pm 0.8$ & 0.23 \\
$\mathrm{PL}+\mathrm{p} 61-75$ & $22.9 \pm 1.6$ & $20.4 \pm 1.1$ & $7.3 \pm 3.1$ & 0.45 \\
$\mathrm{PL}+\mathrm{p} 71-81$ & $25.7 \pm 0.3$ & $22.3 \pm 0.1$ & $22.3 \pm 0.3$ & 0.45 \\
\hline
\end{tabular}

* Pulsation of 20 cycles/min started $10 \mathrm{~s}$ after bubble formation. All values are in dynes/cm and are the mean \pm SEM of at least three determinations.

$\dagger \mathrm{uH} / \mathrm{N}$, hydrophobic moment of peptides.

$\ddagger$ PL, phospholipids at $10 \mathrm{mg} / \mathrm{mL}$.

$\S$ Peptides were $10 \%$ by weight compared with PL.

$\mathrm{cpm} / \mu \mathrm{g}$ dimer/oligomer), perhaps explaining why its activity may be slightly lower at $15 \mathrm{~s}$. It is clear from these data, however, that SP-B monomer is able to cause a significant decrease in surface tension when added to PL.

Synthetic peptide surfactants-in vitro assays. To investigate the mechanism by which SP-B protein augments the surfactant capacity of PL, eight peptides, matching sequential overlapping regions of SP-B, were prepared by simultaneous multiple-peptide solid phase synthesis. The peptides were dissolved or suspended in chloroform/methanol, $1: 1$, and combined with the phospholipids DPPC and PG $(3: 1)$. The various surfactant mixtures were then assayed for biophysical activity in the pulsating bubble surfactometer. The results are shown in Table 2 . All of the peptides tested were able to reduce significantly the surface tension at minimal bubble radius from the values of $>49.0 \pm$ $0.0,48.8 \pm 0.3$, and $46.3 \pm 0.4$ dynes $\cdot \mathrm{cm}^{-1}$ obtained at $15 \mathrm{~s}, 1$ min, and 5 min with the PL alone, with peptides $1-15,11-25$, and $61-75$ being below 10 dynes $\cdot \mathrm{cm}^{-1}$ at $5 \mathrm{~min}$.

Relationship of peptide amphiphilicity and activity. To deter- mine if there was any correlation between the amphiphilicity of a peptide and its activity, hydrophobic moments were calculated for the series of 15-residue peptides taken from throughout the SP-B sequence. These are shown in the right-hand column of Table 2. There was no consistent correlation between hydrophobic moments and activity.

Relationship of SP-B polypeptide size and activity. Because it was apparent that multiple peptides were able to partially reconstitute surfactant activity, we next examined the potential relationship between the length of the SP-B peptide and its capacity to induce surfactant activity. A series of peptides of increasing length matching the carboxy-terminal end of SP-B were prepared (Fig. 3). Each was combined with PL to produce a synthetic surfactant and tested in the pulsating bubble surfactometer. The results are shown in Table 3. A minimal length of at least 17 residues, represented by p64-80, appeared to be necessary to attain surface tensions below 10 dynes $\cdot \mathrm{cm}^{-1}$ by $5 \mathrm{~min}$. An additional series of peptides all having the carboxy-terminal sequence of SP-B ending at residue 81 showed similar results.

To determine if smaller amounts of larger peptides would be effective, the eight peptides shown in Figure 3 were tested at concentrations less than $10 \%$ relative to PL. The results, shown as the average surface tension at minimal bubble radius at $5 \mathrm{~min}$, are tabulated in Table 4 . Although $3 \%$ of the 17-residue peptide reduced the surface tension to 1.6 dynes $\cdot \mathrm{cm}^{-1}$, even $10 \%$ of the slightly smaller 15-residue peptide did not reduce the surface tension below 10 dynes $\cdot \mathrm{cm}^{-1}$. The data suggest that, in this series of peptides, the length and/or the specific residues included in the peptide are more critical to consequent activity than is its relative concentration (at least within the range $1-10 \%$ ).

Various other synthetic peptides based on the sequence of SP$\mathrm{B}$ were prepared, mixed with PL, and analyzed on the pulsating bubble surfactometer for biophysical activity. All showed at least moderate activity (a reduction of surface tension to less than 20 dynes/cm by $5 \mathrm{~min}$ ) when compared with PL alone. The peptides tested were: p12-41, p16-41, p46-76, p51-72, p51-76, p51-77, p53-77, p53-78, p54-72, and p54-76.

A number of peptides unrelated to SP-B were also tested for their ability to lower surface tension when mixed with PL. A wide range of activities was found. Those studies, including an analysis of the characteristics necessary for a peptide to impart reasonable surfactant activity to PL, will be reported separately.

Synthetic peptide surfactants-in vivo assays. The biologic activities of several surfactant mixtures prepared with synthetic peptides derived from the sequence of SP-B were determined in the fetal rabbit model. Static inflation and deflation pulmonary pressure-volume curves were obtained after $30 \mathrm{~min}$ of ventilation after the instillation of the surfactants. Figure 4 shows the results obtained with synthetic surfactants prepared with $1.5 \%$ peptide $1-15,52-81$, or $66-81$. Surfactants incorporating peptides $52-$ 81 and 66-81 resulted in an increase in lung compliance compared with PL alone, whereas the incorporation of $1.5 \%$ peptide 1-15 did not increase compliance.

Dynamic compliance measurements allow one to follow the improvement in compliance over time and were therefore used to analyze the efficacy of many of the synthetic peptide surfactants. Figure 5 shows the computer-generated tracings of dynamic compliance measurements for selected surfactants as a function of time. Natural human surfactant and PL alone are shown as positive and negative controls, respectively. It can be readily seen that all of these synthetic peptide surfactants were able to significantly increase compliance over the values seen with PL alone. It is interesting to note that the kinetics of the synthetic surfactant compliance increases appear to be slower than that seen with natural human surfactant.

\section{DISCUSSION}

This report describes the use of synthetic peptides derived from the sequence of human pulmonary surfactant apoprotein SP-B 


\begin{tabular}{|c|c|c|}
\hline$V C R \perp V L R C S M D$ & $\begin{array}{c}\begin{array}{c}\text { Number of } \\
\text { Residues }\end{array} \\
11\end{array}$ & p70.80 \\
\hline OLVCRLVLRCSMD & 13 & $p 68.80$ \\
\hline$\angle P O L V C R L V L R C S M D$ & 15 & $\mathrm{p} 66 \cdot 80$ \\
\hline LPOLVCRLVLRCSMD & 17 & $p 64 \cdot 80$ \\
\hline$\angle P O L V C R L V L R C S M D$ & 22 & $p 59.80$ \\
\hline
\end{tabular}

DTLLGRLIPQLVCRL VLRCSMD $22 \quad$ p59.80

ERYSVILLDTLLGRMLPQLVCRLVLRCSMD $30 \quad$ p51.80

G ICQCLAERYSVILLDTLLGRLPQLVCRLVLRCSMD $37 \quad$ p44.80

RVVPLVAGGICOCLAERYSVILLDTLLGRMLPQLVCRLVLRCSMD $45 \quad$ p36.80

Fig. 3. Peptides derived from the C-terminus of SP-B.

Table 3. Minimum surface tensions in pulsating bubble assay of peptides of increasing length*

\begin{tabular}{cccr}
\hline & $15 \mathrm{~s}$ & $1 \mathrm{~min}$ & $5 \mathrm{~min}$ \\
\hline PL + p70-80† & $34.9 \pm 0.3$ & $22.7 \pm 1.0$ & $21.6 \pm 0.1$ \\
$\mathrm{PL}+\mathrm{p} 68-80$ & $36.8 \pm 0.9$ & $26.3 \pm 1.1$ & $18.4 \pm 0.5$ \\
$\mathrm{PL}+\mathrm{p} 66-80$ & $30.8 \pm 1.3$ & $22.3 \pm 0.7$ & $18.6 \pm 0.9$ \\
PL + p64-80 & $17.8 \pm 1.3$ & $11.4 \pm 1.4$ & $0.3 \pm 0.3$ \\
PL + p59-80 & $14.7 \pm 0.6$ & $12.2 \pm 0.2$ & $2.7 \pm 1.5$ \\
PL + p51-80 & $20.2 \pm 0.1$ & $19.4 \pm 0.1$ & $3.9 \pm 1.0$ \\
PL + p44-80 & $14.5 \pm 0.2$ & $14.1 \pm 0.7$ & $0.3 \pm 0.3$ \\
PL + p36-80 & $14.9 \pm 0.7$ & $12.2 \pm 1.5$ & $0.0 \pm 0.0$ \\
\hline
\end{tabular}

* Pulsation of 20 cycles/min started $10 \mathrm{~s}$ after bubble formation. All values are in dynes $/ \mathrm{cm}$ and are the mean \pm SEM of at least three determinations.

$\dagger \mathrm{PL}$, phospholipids at $10 \mathrm{mg} / \mathrm{mL}$. Peptides were $10 \%$ by weight compared with PL.

Table 4. Length of peptide vs percent* needed

\begin{tabular}{lcccccc} 
& $\begin{array}{c}\text { No. of } \\
\text { residues }\end{array}$ & \multicolumn{1}{c}{$1 \%$} & $\mathbf{3 \%}$ & $5 \%$ & $7.5 \%$ & $10 \%$ \\
\hline PL + p70-80† & 11 & $20.8 \ddagger$ & 20.2 & 20.4 & 21.2 & 21.6 \\
PL + p68-80 & 13 & 20.4 & 18.6 & 15.7 & 15.9 & 18.4 \\
PL + p66-80 & 15 & 20.6 & 16.7 & 14.3 & 17.6 & 18.6 \\
PL + p64-80 & 17 & 10.6 & 1.6 & 0 & 0 & 0.3 \\
PL + p59-80 & 22 & 6.7 & 1.0 & 2.5 & 0.8 & 2.7 \\
PL + p51-80 & 30 & 11.0 & 3.1 & 1.6 & 6.3 & 3.9 \\
PL + p44-80 & 37 & 7.6 & 8.2 & 2.9 & 4.3 & 0.3 \\
PL + p36-80 & 45 & 8.0 & 0 & 6.3 & 0 & 0 \\
\hline
\end{tabular}

* Percent of peptide relative to PL.

$\dagger$ PL, phospholipids at $10 \mathrm{mg} / \mathrm{mL}$.

$\ddagger$ Results given in dynes/cm of surfactometer bubble assays are given as the mean of at least three determinations of minimal surface tension at $5 \mathrm{~min}$ after bubble formation.

in the production of biologically active pulmonary surfactants. Initial studies showed that the normally dimeric SP-B protein could be reduced and alkylated with the resultant monomeric peptide chains having activity equal to that of the residual dimeric protein after recombination with the phospholipids DPPC and PG (Table 1). It is noteworthy, however, that the activity of the dimer that had undergone the reduction and alkylation procedure but failed to dissociate into separate chains (as analyzed on SDS-PAGE) was less than the activity of untreated SP-B, suggesting that alkylation of one or more of the seven cysteines in this molecule may lower its activity. Attempts
Inflation
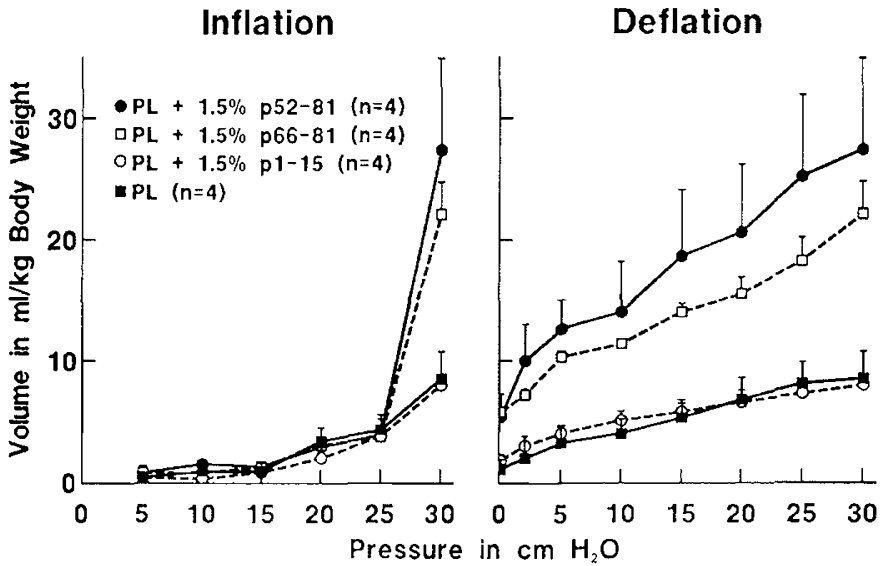

Fig. 4. Inflation and deflation pressure/volume curves of fetal rabbit lungs $30 \mathrm{~min}$ after intratracheal instillation of $2 \mathrm{mg}$ PL alone $(\mathbf{\square}), \mathrm{PL}+$ $1.5 \% \mathrm{p} 1-15(\mathrm{O}), \mathrm{PL}+1.5 \%$ p $66-81(\square)$, or $\mathrm{PL}+1.5 \% \mathrm{p} 52-81(\bullet)$ Data are expressed as the mean of four animals $\pm 1 \mathrm{SD}$.

to repeat those studies in the absence of alkylating agents were not successful due to the propensity of the single chains to redimerize.

The ability to show activity in the pulsating bubble assay of SP-B monomer after recombination with PL led to the question of whether all 80 or 81 residues were required for this activity. Our initial screening of 15-residue overlapping segments of the molecule showed that biophysical activity could be obtained with most peptide segments (Table 2). In studies to be reported separately, we have shown that amino acid sequences unrelated to the SP-B sequence, but consisting of various combinations of hydrophobic and hydrophilic residues, can also mimic this activity when appropriately recombined with PL. In a recent publication, Venkitaraman et al. (35) showed that mixtures of DPPC or DPPC/PG $(8: 2)$ with polyleucine or polyphenylalanine are able to lower surface tension significantly, whereas the more hydrophilic peptides, polyserine, polylysine, and polyglutamic acid show little or no such ability. Polyvaline, however, which has nearly the same hydrophobicity index as polyleucine, failed to lower surface tension or improve adsorption when added to the PL, although the authors propose that this may be due to poor mixing of this particular peptide with the lipids. The data presented in our current study (Table 2) do not support a clear relationship between hydrophobic moments (as a measure of amphipathicity) and the surfactant-inducing capacity of the individual peptides. 


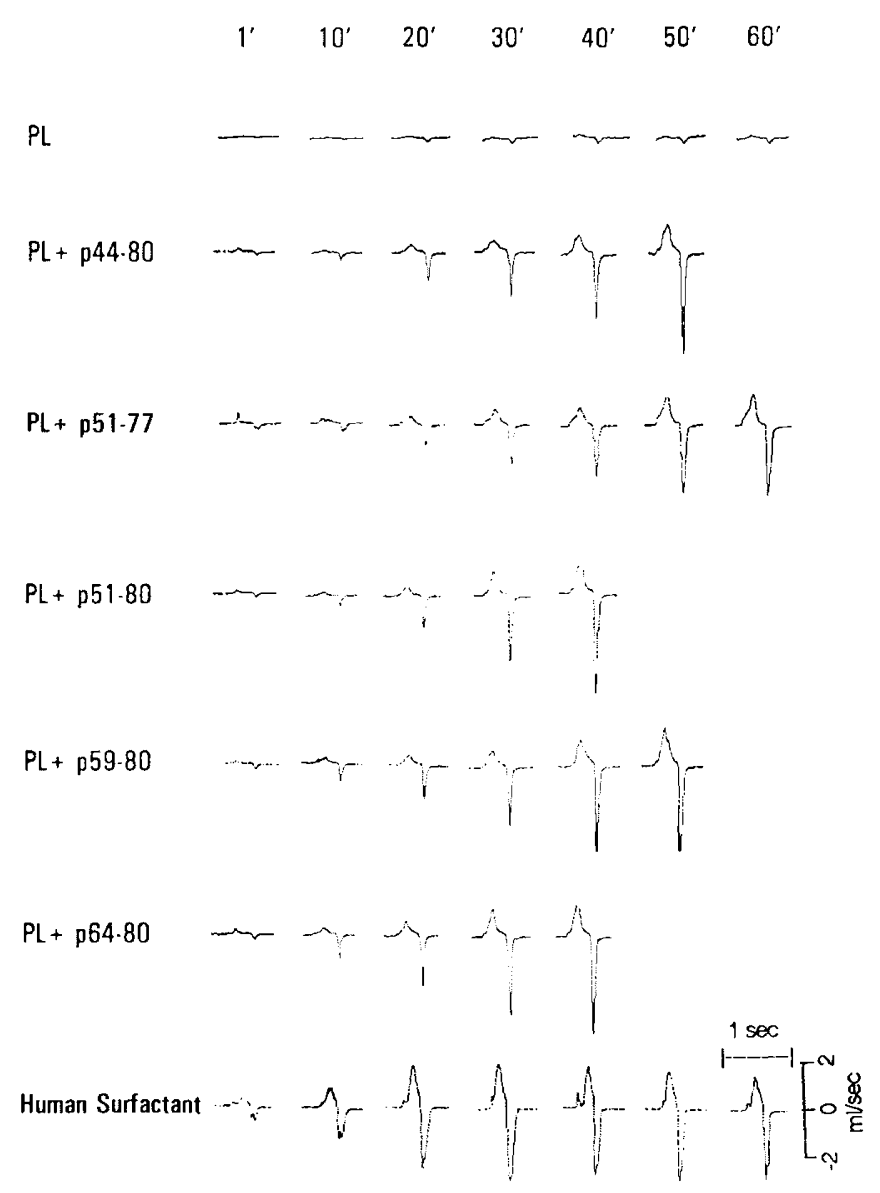

Fig. 5. Computer-generated tracings showing the airflow into and out of fetal rabbit lungs during one respiratory cycle at various times after instillation of several synthetic surfactants, PL alone, or human surfactant isolated from amniotic fluid. Tracings are from a single animal in each group and are representative of at least three animals given the indicated surfactant. Scale used is shown on human surfactant tracing.

To investigate the influence of chain length on surfactantinducing capacity, a number of synthetic peptides derived from the carboxy-terminal sequence of SP-B were prepared (Fig. 3) and their abilities to lower the surface tension of a pulsating bubble after reconstitution with PL were tested. The results are shown in Table 3 . The data suggest that, in this series of peptides, a minimum chain length of approximately 17 residues is necessary. Although the 15-residue peptide in this series (p66-80) did not result in extremely low surface tensions, other 15 -residue peptides have been shown to result in surfactants of adequate surface-tension lowering capacity (see Table 2). The high density of hydrophilic amino acids, especially the negatively charged aspartic acid, found at the carboxy terminus of SP-B may preclude this five- or six-residue "tail" from participating in the lipid/protein interaction that appears to be necessary for biophysical activity. Thus, the 15-residue peptide 66-80 may only function as a 10-residue peptide in this regard. Aside from an increase in length by two residues, it is possible that p64-80 functions better than p66-80 in lowering surface tension because of the inclusion of the specific residue(s) arginine and/or methionine (residues 64 and 65) at the amino terminus. Peptide 6680 contains only three highly charged residues, whereas p64-80 contains four. Perhaps this is a critical difference.

The relationship between peptide length and concentration required for surfactant-inducing capacity was studied. Increasing the concentration of peptides $\leq 15$ residues in length (up to $10 \%$ ) did not generate greater activity (Table 4). In addition, no consistent dose-response relationship between 1 and $10 \%$ peptide could be established using peptides of length $\geq 17$ residues. Per- haps concentrations less than $1 \%$ peptide (e.g. $\geq 1$ molecule p6480 per 270 molecules $\mathrm{PL}$ ) would have shown a dose-response relationship.

No attempt was made in these studies to determine the extent of oligomerization of these cysteine-containing peptides. It is possible that the peptides, although stored under vacuum, when formulated into the synthetic surfactants, may undergo varying amounts of dimerization or larger aggregation. The native SP-B molecule prefers to exist in a dimeric state, although it is unknown which cysteine(s) are involved. Waring et al. (36), in a recent study utilizing a cysteine-containing SP-B peptide (p125 ), found the peptide to be present in both monomeric and oligomeric forms. The use of noncysteine-containing analogues of the peptides would allow determination of the role of cysteine in the activities of these peptides.

Synthetic surfactants prepared with selected peptides were instilled into the airways of surfactant-deficient fetal rabbits to show the biologic activity of which these samples are capable. Static pressure/volume curves generated $30 \mathrm{~min}$ after surfactant instillation indicated a moderate, although significant, increase in compliance for peptides 52-81 and 66-81 and no increase above the values obtained with PL alone with peptide 1-15 (Fig. 4). Although greater activity might have been seen if a higher concentration of peptide $(>1.5 \%)$ had been used in these studies, it is apparent that in vivo activity does not necessarily correspond to that obtained in vitro. Additionally, differential susceptibility to inhibition by proteins present in the airways could contribute to discrepancies between in vitro and in vivo activities. It is surprising, however, that p66-81, which had in vitro activity similar to p66-80 (Table 4), was fairly active in the fetal rabbit assay. Perhaps different inhibitor susceptibilities are playing a role here as well.

The ability to perform dynamic compliance measurements aided greatly our efforts to determine biologic activity of the various surfactants. The data, examples of which are shown in Figure 5, show not only the compliance at the end of the experiment, but also the kinetics of the compliance increases. Analysis of the data shows that, although various synthetic peptide surfactants do result in greatly increased lung compliance, the rate of compliance increase is generally slower than that seen with native human surfactant. This may be due to the relatively high degree of saturation in the PL used in these studies. Although the egg PG we used contains approximately $50 \%$ unsaturated fatty acids, the PC was all saturated (dipalmitoyl) in contrast with the PC in native human surfactant, which is only $66 \%$ disaturated (24). A very comprehensive analysis of the components required for maximally active synthetic lung surfactants by Tanaka et al. (22) included a requirement for a free, saturated fatty acid, such as palmitic or stearic, in addition to an acidic PL, such as PG. Using the Tanaka lipid mixture, Waring et al. (36) was able to show that SP-B synthetic peptides p1-25 and p49-66 (with norleucine substituted for methionine) associated with and ordered the lipids in a manner similar to native SP-B. Studies are currently underway in our laboratory to investigate the biophysical and physiologic ramifications of varying both the degree of lipid saturation and the inclusion of FFA into surfactant mixtures based upon synthetic peptides. Such studies, along with the optimization of the peptide to lipid ratio, and analysis of the other variables in the formulation procedure, may lead to a synthetic surfactant having biologic activity equal to, or surpassing, that of human surfactant isolated from amniotic fluid, as well as further our understanding of the mechanism of surfactant function.

Acknowledgments. The authors thank Annelise Heldt, Joan Sorg, David Price, and Wade Rich for their expert technical assistance with the fetal rabbit studies and Katherine Holcomb for assistance in isolation of surfactant from human amniotic fluid. We also thank Mark Feinstein and Farshad Karimi for their assistance in the production of synthetic peptides. This is 
publication no. 5915-IMM from the Department of Immunology Research Institute of Scripps Clinic, La Jolla, CA.

\section{REFERENCES}

1. Curstedt T, Johansson J, Barros-Soderling J, Robertson B, Nilsson G, Westberg M, Jornvall H 1988 Low-molecular mass surfactant protein type 1. Eur J Biochem 172:521-525

2. Curstedt T, Jornvall H, Robertson B, Bergman T, Berggren P 1987 Two hydrophobic low-molecular-mass protein fractions of pulmonary surfactant. Characterization and biophysical activity. Eur J Biochem 168:255-262

3. Glasser WS, Korfhagen TR, Weaver T, Pilot-Matias T, Fox JL, Whitsett JA $1987 \mathrm{cDNA}$ and deduced amino acid sequence of human pulmonary surfactant-associated proteolipid SPL(Phe). Proc Natl Acad Sci USA 84:40074011

4. Hawgood S, Benson BJ, Schilling J, Damm D, Clements JA, White RT 1987 Nucleotide and amino acid sequences of pulmonary surfactant protein SP18 and evidence for cooperation between SP18 and SP28-36 in surfactant lipid adsorption. Proc Natl Acad Sci USA 84:66-70

5. Jacobs KA, Phelps DS, Steinbrink R, Fisch J, Krij R, Mitsock L, Dougherty JP, Taeusch HW, Floros J 1987 Isolation of a cDNA clone encoding a high molecular weight precursor to a $6-\mathrm{kDa}$ pulmonary surfactant-associated protein. J Biol Chem 262:9808-9811

6. Johansson J, Jornvall H, Eklung A, Christensen N, Robertson B, Curstedt $T$ 1988 Hydrophobic 3.7 kDa surfactant polypeptide: structural characterization of the human and bovine forms. FEBS Lett 242:61-64

7. Notter RH, Shapiro DL, Ohning B, Whitsett JA 1987 Biophysical activity of synthetic phospholipids combined with purified lung surfactant 6000 dalton apoprotein. Chem Phys Lipids 44:1-17

8. Phelps DS, Smith LM, Taeusch HW 1987 Characterization and partial amino acid sequence of a low molecular weight surfactant protein. Am Rev Respir Dis 135:1112-1117

9. Phizackerley PJR, Town MH, Newman GE 1979 Hydrophobic proteins of lamellated osmiophilic bodies isolated from pig lung. Biochem J 183:731736

10. Revak SD, Merritt TA, Degryse E, Stefani L, Courtney M, Hallman M, Cochrane CG 1988 Use of human surfactant low molecular weight apoproteins in the reconstitution of surfactant biologic activity. J Clin Invest 81:826833

11. Suzuki Y, Curstedt T, Grossman G, Kobayashi T, Nilsson R, Nohara K, Robertson B 1986 The role of the low-molecular weight ( $\leq 15000$ daltons) apoproteins of pulmonary surfactant. Eur J Respir Dis 69:336-345

12. Suzuki $Y$, Kogishi K, Fujita Y, Kina T, Nishikawa S 1986 A monoclonal antibody to 15,000 dalton protein associated with porcine pulmonary surfactant. Exp Lung Res 11:61-73

13. Takahashi A, Fujiwara T 1986 Proteolipid in bovine lung surfactant: its role in surfactant function. Biochem Biophys Res Commun 135:527-532

14. Taeusch HW, Keough KMW, Williams M, Slavin R, Steele E, Lee AS, Phelps D, Kariel N, Floros J, Avery ME 1986 Characterization of bovine surfactant for infants with respiratory distress syndrome. Pediatrics 77:572-581

15. Warr RG, Hawgood S, Buckley DI, Crisp TM, Schilling J, Benson BJ, Ballard PL, Clements JA, White RT 1987 Low molecular weight human pulmonary surfactant protein (SP 5): isolation, characterization, and cDNA and amino acid sequences. Proc Natl Acad Sci USA 84:7915-7919

16. Whitsett JA, Hull WM, Ohning B, Ross G, Weaver TE 1986 Immunologic identification of a pulmonary surfactant-associated protein of molecular weight $=6000$ daltons. Pediatr Res 20:744-749
17. Whitsett JA, Ohning BL, Ross G, Meuth J, Weaver T, Holm BA, Shapiro DL, Notter RH 1986 Hydrophobic surfactant-associated protein in whole lung surfactant and its importance for biophysical activity in lung surfactant extracts used for replacement therapy. Pediatr Res 20:460-467

18. Yu S-H, Possmayer F 1986 Reconstitution of surfactant activity associated with pulmonary surfactant. Biochem J 236:85-89

19. Yu S-H, Possmayer F 1988 Comparative studies on the biophysical activities of the low-molecular-weight hydrophobic proteins purified from bovine pulmonary surfactant. Biochem Biophys Acta 961:337-350

20. Possmayer $F 1988 \mathrm{~A}$ proposed nomenclature for pulmonary surfactant-associated proteins. Am Rev Respir Dis 138:990-998

21. Robertson B, Curstedt T, Grossmann G, Kobayashi T, Kokubo M, Suzuki Y 1988 Prolonged ventilation of the premature newborn rabbit after treatment with natural or apoprotein-based artificial surfactant. Eur J Pediatr 147:168173

22. Tanaka Y, Takei T, Aiba T, Masuda K, Kiuchi A, Fujiwara T 1986 Development of synthetic lung surfactants. J Lipid Res 27:475-485

23. Yu S-H, Wallace D, Bhavnani B, Enhorning G, Harding PGR, Possmayer F 1988 Effect of reconstituted pulmonary surfactant containing the 6000 dalton hydrophobic protein on lung compliance of prematurely delivered rabbit fetuses. Pediatr Res 23:23-30

24. Hallman M, Merritt TA, Schneider M, Epstein BL, Mannino F, Edwards DK, Gluck L 1983 Isolation of human surfactant from amniotic fluid and a pilot study of its efficacy in respiratory distress syndrome. Pediatrics 71:473-482

25. Hallman M, Merritt TA, Jarvenpaa AL, Boynton B, Mannino F, Gluck L, Moore T, Edwards D 1985 Exogenous human surfactant for treatment of severe respiratory distress syndrome: a randomized prospective clinical trial. J Pediatr 106:963-969

26. Merritt TA, Hallman M, Bloom BT, Berry C, Benirschke K, Sahn D, Key T, Edwards D, Jarvenpaa AL, Pohjavriori M, Kanakaanpaa K, Kunnas M, Paatero M, Rapola J, Jaaskelainen J 1986 Prophylactic treatment of very premature infants with human surfactant. N Engl J Med 315:785-790

27. Tooley WH, Clements JA, Muramatsu K, Brown CL, Schlueter MA 1987 Lung function in prematurely delivered rabbits treated with a synthetic surfactant. Am Rev Respir Dis 136:651-656

28. Houghten RA 1985 General method for the rapid solid-phase synthesis of large numbers of peptides: specificity of antigen-antibody interaction at the level of individual amino acids. Proc Natl Acad Sci USA 82:5131-5135

29. Merrifield RB 1963 Solid phase peptide synthesis. I. The synthesis of a tetrapeptide. J Am Chem Soc 85:2149-2154

30. Sakakibara S, Shimonishi Y 1965 A new method for releasing oxytocin from fully-protected nona-peptides using anhydrous hydrogen fluoride. Bull Chem Soc Japan 38:1412-1413

31. Lenard J, Robinson AB 1967 Use of hydrogen fluoride in Merrifield solidphase peptide synthesis. J Am Chem Soc 89:181-182

32. Revak SD, Merritt TA, Hallman M, Cochrane CG 1986 Reconstitution of surfactant activity using purified human apoprotein and phospholipids measured in vitro and in vivo. Am Rev Respir Dis 134:1258-1265

33. Laemmli UK 1970 Cleavage of structural proteins during the assembly of the head of bacteriophage T4. Nature 227:680-685

34. Eisenberg D, Weiss RM, Terwilliger TC 1984 The hydrophobic moment detects periodicity in protein hydrophobicity. Proc Natl Acad Sci USA 81:140-144

35. Venkitaraman AR, Hall SB, Notter RH 1990 Hydrophobic homopolymeric peptides enhance the biophysical activity of synthetic lung phospholipids Chem Phys Lipids 53:157-164

36. Waring A, Taeusch W, Bruni R, Amirkhanian J, Fan B, Stevens R, Young J 1989 Synthetic amphipathic sequences of surfactant protein-B mimic several physicochemical and in vivo properties of native pulmonary surfactant proteins. Pept Res 2:308-313 